\title{
ASSESSMENT OF GENOTYPE $\times$ ENVIRONMENT INTERACTION FOR GRAIN PROTEIN CONTENT IN SHORT- SEASON SOYBEAN GENOTYPES
}

\author{
Vesna Perić ${ }^{\star}$, Mirjana Srebrić1 ${ }^{1}$ Jelena Srdić ${ }^{1}$, Danijela Ristić
}

\begin{abstract}
The protein content is an important parameter of the technological quality of soybean grain. Therefore, the selection work is aimed at creating a genetic basis for obtaining varieties not only of high yield but also varieties of improved grain quality. In order to provide sustained progress in breeding, it is necessary to find a stable source for breeding for desired traits. The aim of this study was to examine the value of the genotype $\times$ environment $(\mathrm{G} \times \mathrm{E})$ interaction for protein content in 14 Maize Research Institute "Zemun Polje” short-season soybean accessions and to identify stable sources that can be used in breeding for protein content improvement. G×E interaction for grain protein content was analyzed using a linear-bilinear AMMI-1 model. The influence of genotype and environment on the total variation of protein content was approximately equal, while the smallest variation is attributed to genotype $x$ environment interaction. A large number of genotypes with different protein content (Korana, PI 180 507, Kabott, Krajina, Canatto) showed a small contribution to the interaction in studied environments, the most important of which were genotypes with above-average protein content, as potential sources for future breeding programs.
\end{abstract}

Key words: Glycine max, technological quality, AMMI-1model

\section{Introduction}

The modern processing industry requires soybean varieties characterized by good parameters of technological quality of the grain, the most important of which are protein and oil content. Therefore, the breeding work is aimed at creating a genetic basis for obtaining varieties not only of high yield but also varieties of improved grain quality (Miklič et al., 2018). The major problem in obtaining high yielding and high protein soybean cultivars is the negative correlation between oil and protein content as well as the negative correlation between protein and grain yield (Voldeng et al., 1997; Cober and Voldeng, 2000). Furthermore, seed protein content is a quantitative trait determined by a number of genes with minor or major effect (Hyten et al., 2004), and largely depends on environmental factors as well as genotype $\times$ environment interactions
(Miladinović et al., 1996; Balešević-Tubić et al., 2011). The interaction of genotype $\times$ environment implies an inconsistent reaction of the genotype to changes in environmental conditions (Baker, 1988). From the breeding aspect, interaction is an aggravating factor in selection, because the participation of the interaction component in the total variability reduces the heritability of the trait, and thus the reliability of selection based on the main components (Kelly et al., 1998; Kang, 2004). The interaction obscures the agronomic value of the introduced material (Giaufrett et al., 2000), which has recently become increasingly important in soybean breeding, given the dramatic narrowing of the genetic basis due to breeding within elite lines. The introduced germplasm is generally a poorly adapted, so for the successful integration of genes into elite soybean varieties, it is necessary to determine

Original Scientific Paper (Originalni naučni rad)

${ }^{1}$ Perić V, Srebrić M, Srdić J, Ristić D, Institut za kukuruz „Zemun Polje”, Slobodana Bajića 1, 11185 Zemun Polje, Beograd ‘ e-mail: vperić@mrizp.rs 
the stability of the introduced sources (Palomeque et al., 2009). A large number of statistical models have been developed to assess genotype $\times$ environment interactions, with AMMI (Additive Main effects and Multiplicative Interaction) and GGE models being the most commonly used to determine genotype response patterns across different environments (Gauch and Zobel, 1998; Yan and Rajcan, 2002).

In this study, the AMMI-1 model was applied in order to identify genotypes with above-average grain protein value and good stability, which may have a potential contribution to breeding, and to analyze the influence of agroecological factors in individual environments on the variability of the seed protein content.

\section{Material and methods}

The experiment included 14 soybean genotypes of maturity group 00 (very early varieties), maintained in soybean collection of Maize Research Institute "Zemun Polje”. Field trials were set up over two years (2011 and 2012), at two locations (Zemun Polje and Pančevo), according to a randomized complete block (RCB) design with three replications and experimental unit area $5 \mathrm{~m}^{2}$. The harvest was carried out with plot combine. The content of total proteins in grain was measured on
NIRT (near infra-red transmission) analyzer "Infraneo"®, Chopin Technologies and expressed in percentage (\%) on a dry matter basis. The data were analyzed by a linear mixed model of classical analysis of variance with a random effect of blocks within the environment. Differences between genotype pairs over 4 environments and differences between means of environments were tested using Tukey's multiple comparison test. Interaction of genotype and environment for grain protein content was analyzed using a linear-bilinear AMMI-1 model (Crossa et al., 1990).

\section{Results and discussion \\ Meteorological conditions}

The years and locations of the experiment varied greatly regarding meteorological conditions (Table 1). In general, both years were dry, while 2012 appeared to be among the driest growing seasons in the history of meteorological observations. The sum of precipitation in June, July and August 2011 was three times higher than in 2012 at location Zemun Polje and almost four times higher than in 2012 at location Pančevo. In these months $(6,7$ and 8$)$ soybean is passing through a reproductive stage and is highly sensitive to drought (the critical period for water).

Table 1. Average monthly temperatures $(T)$ and precipitations $(P)$ in two locations during the 2011. and 2012. years Tabela 1. Prosečne mesečne temperature (T) i padavine (P) na dve lokacije u toku 2011. i 2012. godine

\begin{tabular}{|c|c|c|c|c|c|c|c|c|}
\hline \multirow{3}{*}{ Month } & \multicolumn{4}{|c|}{ Zemun Polje } & \multicolumn{4}{|c|}{ Pančevo } \\
\hline & \multicolumn{2}{|r|}{2011.} & \multicolumn{2}{|c|}{2012.} & \multicolumn{2}{|c|}{2011.} & \multicolumn{2}{|c|}{2012.} \\
\hline & $\mathrm{T}\left({ }^{\circ} \mathrm{C}\right)$ & $\mathbf{P}\left(\mathbf{m m ~ \mathbf { m } ^ { - 2 } )}\right.$ & $\mathrm{T}\left({ }^{\circ} \mathrm{C}\right)$ & $\mathbf{P}\left(\mathbf{m m ~ m}^{-2}\right)$ & $\mathrm{T}\left({ }^{\circ} \mathrm{C}\right)$ & $\mathbf{P}\left(\mathbf{m m ~ m}^{-2}\right)$ & $\mathrm{T}\left({ }^{\circ} \mathrm{C}\right)$ & $\mathbf{P}\left(\mathrm{mm} \mathrm{m}^{-2}\right)$ \\
\hline 4. & 14.6 & 14.9 & 13.0 & 56.2 & 14.0 & 9.3 & 13.8 & 86.0 \\
\hline 5. & 17.3 & 89.6 & 17.9 & 58.5 & 17.7 & 113.2 & 18.4 & 99.8 \\
\hline 6. & 22.3 & 26.2 & 24.4 & 14.8 & 24.8 & 93.1 & 24.3 & 9.6 \\
\hline 7. & 24.1 & 44.0 & 27.1 & 19.8 & 22.9 & 67.0 & 26.7 & 37.1 \\
\hline 8. & 24.7 & 66.0 & 26.2 & 4.8 & 24.1 & 18.7 & 25.4 & 1.5 \\
\hline 9. & 23.2 & 32.4 & 22.3 & 20.7 & 21.8 & 29.1 & 21.1 & 28.5 \\
\hline \multirow[t]{2}{*}{$\begin{array}{l}\text { Vegetation } \\
\text { period }\end{array}$} & $\mathrm{T}_{\mathrm{sr}}=21.1$ & $\Sigma=273.10$ & $\mathrm{~T}_{\mathrm{sr}}=21.82$ & $\Sigma=174.8$ & $\mathrm{~T}_{\mathrm{sr}}=20.9$ & $\Sigma=330.4$ & $\mathrm{~T}_{\mathrm{sr}}=21.6$ & $\Sigma=262.5$ \\
\hline & & $\Sigma_{6,7,8}=136.2$ & & $\Sigma_{6,7,8}=39.4$ & & $\Sigma_{6,7,8}=178.8$ & & $\Sigma_{6,7,8}=48.2$ \\
\hline
\end{tabular}




\section{Grain protein content}

Analysis of variance (mixed model) revealed that the influence of genotype, environment (season and location) and their interaction on soybean grain protein content was highly significant $(P<0.01)$. Almost equal influence of genotype and environment on the variation of protein content suggested that examined soybean genotypes were less responsive to environmental changes. Similar findings were reported by Miladinović et al. (2006) who tested 4 Serbian soybean cultivars in 6 environments and found that the influence of genotype and environment on the total variation of protein content was approximately equal, while the smallest part of the variation is attributed to genotype $\mathrm{x}$ environment interaction. In research by Sudarić et al. (2006) and Vollmann et al. (2000a) environment has proven to be the most important source of variation, while less variation is attributed to the effects of genotype and genotype $\mathrm{x}$ environment interaction.

Table 2: ANOVA-mixed model F-test values for seed protein content in 14 soybean genotypes

Tabela 2. Vrednosti F-testa iz ANOVA mešovitog modela za sadržaj proteina 14 genotipova

\begin{tabular}{cc}
\hline Source of variation & F-test values \\
\hline Genotype $(\mathrm{G})$ & $86.3^{* *}$ \\
Environment $(\mathrm{E})$ & $83.5^{\star *}$ \\
Gx E & $5.0^{* *}$ \\
\hline
\end{tabular}

${ }^{*}$ statistically highly significant at $P<0.01$ level

Table 3. The average grain protein content of 14 soybean genotypes at Zemun Polje (ZP) and Pančevo (PA) during 2011. and 2012. years

Tabela 3. Prosečan sadržaj proteina u semenu kod 14 genotipova soje u Zemun Polju (ZP) i Pančevu (PA) tokom 2011. i 2012. godine

\begin{tabular}{lccccc}
\hline \multirow{2}{*}{ Genotype } & \multicolumn{5}{c}{ Protein content (\%) } \\
\cline { 2 - 6 } Progres & ZP 2011 & ZP 2012 & PA 2011 & PA 2012 & Mean \\
Agassiz & 41.6 & 44.9 & 40.4 & 44.0 & $42.8^{\mathrm{a}}$ \\
Evrika & 38.8 & 40.1 & 37.3 & 38.7 & $38.8^{\mathrm{fg}}$ \\
Gi 291/70-79 & 39.1 & 41.5 & 38.1 & 39.2 & $39.5^{\mathrm{de}}$ \\
Kabott & 36.7 & 38.9 & 37.6 & 36.2 & $37.3^{\mathrm{i}}$ \\
Ljuso & 42.4 & 42.4 & 40.1 & 41.3 & $41.6^{\mathrm{b}}$ \\
Maple Arrow & 39.5 & 40.3 & 38.5 & 38.4 & $39.2^{\mathrm{ef}}$ \\
Maple Presto & 39.1 & 41.9 & 38.9 & 39.0 & $39.7^{\mathrm{cd}}$ \\
Mini Soja & 40.2 & 40.8 & 39.3 & 39.3 & $39.9^{\mathrm{cd}}$ \\
Canatto & 44.3 & 43.0 & 43.8 & 41.5 & $43.2^{\mathrm{a}}$ \\
PI 180 507 & 43.1 & 44.7 & 41.2 & 41.6 & $42.6^{\mathrm{a}}$ \\
Korana & 39.9 & 40.8 & 39.4 & 39.9 & $40.0^{\text {cd }}$ \\
Olima & 38.6 & 39.3 & 37.6 & 38.0 & $38.4^{\mathrm{gh}}$ \\
Krajina & 38.7 & 40.4 & 36.0 & 36.3 & $37.9^{\mathrm{h}}$ \\
Mean. & 39.8 & 41.0 & 39.8 & 39.8 & $40.1^{\mathrm{c}}$ \\
\hline
\end{tabular}

The values of genotypes marked with the same letters did not differ at significance level 0.05 . 
Average seed protein content per environment varied from $39,1 \%$ to $41,4 \%$ (Table 3). Genotypes tested at location Zemun Polje during the year 2012 had the highest mean for protein content. At the same time, the mentioned environment had the lowest precipitation in June, July and August, suggesting that high temperatures and water deficiency could favour protein synthesis. In soybean genotypes of early maturity groups, average to high proteins were found in years with high temperatures and moderate rainfalls, while seed protein concentration was reduced in years with greater precipitation during a period of seed filling (Vollmann et al., 2000b). Similar findings were reported by Dornbos and Mullen (1992), who found that severe drought increased protein content by 4.4 percent, while oil content decreased, by 2.9 percent. Average seed protein content in 14 genotypes over two years and two locations varied from 37,9\% to $43,2 \%$. Genotypes Progres, Mini Soja and Canatto had a significantly higher protein content compared to other genotypes in the group, representing a potentially valuable source for breeding for protein content.

Among different models for $\mathrm{G} \times \mathrm{E}$ interaction assessment, the AMMI-1 method has proven to be effective in predicting the performance of soybean genotypes in different environments (Faria et al., 2016; Souza et al., 2015), providing the possibility of graphical representation of the interaction on a biplot, where the values of the main effects (genotypes, environments) are presented on the abscissa, and the values of the first interaction axis (IPC1) on the ordinate (Crossa et al., 1990). A large part of the variation $(59.9 \%)$ of the genotype $\times$ environment interaction for grain protein content in 14 soybean genotypes was explained by the first interaction axis of the AMMI-1 model (Figure 1). The differences in the main effects of four environments were not large, since all environments had a protein content close to the general mean which was $40,1 \%$.

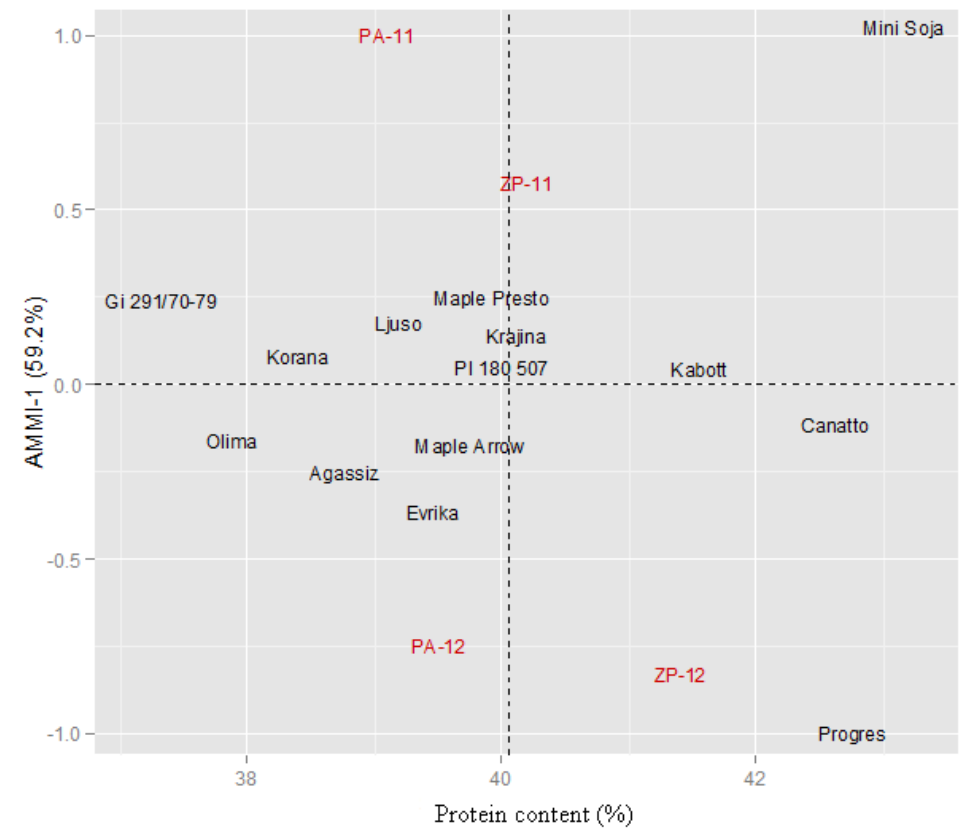

Figure 1. AMMI-1 biplot of 14 soybean varieties in 4 environments (ZP-Zemun Polje, PA-Pančevo, 11 i 12 years of experiment)

Grafikon 1. AMMI-1 biplot 14 genotipova soje u 4 sredine (ZP-Zemun Polje, PA-Pančevo, 11 i 12 -godine ispitivanja) 
The interaction effect of the four environments on genotypes was mostly variable. Both test sites showed a positive interaction effect in 2011 and a negative interaction effect in 2012. Genotypes tested in Pančevo in 2011 were the most unstable, while the genotypes tested in 2012 showed approximately equal stability at both sites. Most of the studied genotypes were distributed around the average protein content, while the value of the interaction component differed mainly. The genotypes with interaction scores close to zero contributed little to the interaction and were considered stable (Korana, PI 180 507, Kabott, Krajina, Canatto). Among them, genotypes of above-average protein content (Kabott and Canatto) are potentially of the greatest importance for designing parental combinations in breeding for protein content. Although the Mini Soja and Progress genotypes were characterised by very high protein content, the high value of the interaction limits their importance and use in the selection program to improve the technological quality of grain.

\section{Conclusion}

According to the results of our study, AMMI-1 method could be used as an efficient tool for better prediction of phenotypic stability of genotypes grown in different environments. Among the number of genotypes which showed good stability, two genotypes - Kabott and Cannatto were distinguished for being stable and having a high mean for grain protein content. These genotypes could represent a potential source in breeding for enhanced quality of soybean grain.

\section{Acknowledgement}

This paper is supported by the Ministry of Education, Science and Technological Development, Republic of Serbia.

\section{References}

Baker RJ (1988): Tests for cross-over genotype $\mathrm{x}$ environment interactions. Can. J. Plant Sci. 68: 405-410.
Balešević-Tubić S, Đorđević V, Miladinović J, Đukić V, Tatić M (2011): Stability of soybean seed composition, Genetika, 43(2): 217-227.

Cober ER, Voldeng HD, Fregeau-Reid JA (1997): Heritability of seed shape and seed size in soybean. Crop Sci. 37: 1767-1769.

Crossa J, Gauch HG, Zobel RW (1990): Additive Main Effects and Multiplicative Interaction Analysis of two international maize cultivar trials. Crop Sci. 30:493-500.

Dornbos DLJr., Mullen RE (1992): Soybean seed protein and oil contents and fatty acid composition adjustments by drought and temperature. J. Am. Oil Chem. Soc. 69(3): 228-231.

Faria PN, Santos Dias CT, Pinheiro JB, Araújo LB, Cirillo MA , Carvalho Araújo MF (2016): AMMI methodology in soybean: Cluster analysis with bootstrap resampling in genetic divergence and stability. Rev. Ceres, Viçosa, v. 63, n.4, p. 461-468

Gauch HG, Zobel RW (1996): AMMI analysis of yield trials. In: Kang M.S., H.G. Gauch, (ed). Genotype by environment interaction. CRC Press, Boca Raton, 85-122.

Giauffret C, Lothrop J, Dorvillez D, Gouesnard B, Derieux M (2000): Genotype x environment interactions in maize from temperate or highland tropical origin. Crop Sci. 40: 1004-1012

Hyten DL, Pantalone VR, Sams CE, Saxton AM, Landau-Ellis D, Stefaniak TR, Schmidt ME (2004): Seed quality QTL in a prominent soybean population. Theor. Appl. Genet. 109: 552-561.

Kang MS (2004): Breeding: Genotype by environment interaction. Encyclopedia of Plant and Crop Sci. 218-221.

Kelly JD, Kolkman JM, Schneider K (1998): Breeding for yield in dry bean (Phaseolus vulgaris L.). Euphytica 102: 343-356.

Miklič V, Ovuka J, Marjanović-Jeromela A, Terzić S, Jocić S, Cvejić S, Miladinović D, Hladni N, Radić V, Ostojić B, Jocković M, Dušanić N, Đorđević V, Miladinović J, Balešević-Tubić S, Balalić I (2018): Breeding and seed production of oil crops in Serbia. Selekcija i semenarstvo 24(2): 1-9. 
Miladinović J, Hrustić M, Vidić M, Tatić M (1996): Path coefficient analysis of effect of yield, oil content and the duration of vegetative and reproductive periods on seed protein content in soybean. Eurosoya 10:51-56.

Miladinovic J, Kurosaki H, Burton JW, Hrustic M, Miladinovic D (2006): The adaptability of shortseason soybean genotypes to varying longitudinal regions. Europ. J. Agronomy 25: 243-249.

Palomeque L, Jun LL, Li W, Hedges B, Cober ER, Rajcan I (2009): QTL in megaenvironments: II. Agronomic trait QTL colocalized with seed yield QTL detected in a population derived from a cross of highyielding adapted $\mathfrak{E}$ high-yielding exotic soybean lines. Theor. Appl. Genet. 119: 429-436

Sousa LB, Hamawaki OT, Nogueira APO, Batista RO, Oliveira VM, Hamawaki RL (2015): Evaluation of soybean lines and environmental stratification using the AMMI, GGE biplot, and factor analysis methods. Genet. Mol. Res. 14 (4): 1266012674 (2015)
Sudarić A, Vratarić M, Rajcan I (2006): Evaluation of agronomic performance of domestic and exotic soybean germplasm in Croatia. Poljoprivreda 12(2): 17-22.

Voldeng HD, Cobber ER, Hume DJ, Gillard C, Morrison MJ (1997): Fifty-eight years of genetic improvement of short season soybean cultivars in Canada. Crop Sci. 37: 428-431

Vollmann J, Winkler J, Fritz CN, Grausgruber H, Ruckenbauer P (2000a): Spatial field variations in soybean (Glycine max (L.) Merr.) performance trials affect agronomic characters and seed composition. Eur. J. of Agron. 12: 13-22.

Vollmann J, Fritz CN, Wagentristl H, P. Ruckenbauer P (2000b): Environmental and genetic variation of soybean seed protein content under Central European growing conditions. J. Sci. Food Agric. 80(9): 1300-1306.

Yan W, Rajcan I (2002): Biplot analysis of test sites and trait relations of soybean in Ontario. Crop Sci. 42: 11-20. 


\title{
PROCENA INTERAKCIJE GENOTIP $\times$ SPOLJAŠNJA SREDINA ZA SADRŽAJ PROTEINA U ZRNU KOD RANOSTASNIH GENOTIPOVA SOJE
}

\author{
Vesna Perić, Mirjana Srebrić, Jelena Srdić, Danijela Ristić
}

\begin{abstract}
Sažetak
Sadržaj proteina važan je parametar tehnološkog kvaliteta zrna soje. Stoga je oplemenjivački rad usmeren na stvaranje genetičke osnove za dobijanje sorti ne samo visokog prinosa, već i sorti poboljšanog kvaliteta zrna. U cilju obezbeđivanja dugoročnog napretka u selekciji važno je pronaći stabilne izvore za oplemenjivanje na željeno svojstvo. Cilj rada bio je da se ispita vrednost interakcije genotip $\times$ spoljašnja sredina $(G \times E)$ za sadržaj proteina kod 14 veoma ranih genotipova soje kolekcije Instituta za kukuruz „Zemun Polje“ i da se identifikuju stabilni izvori koji mogu poslužiti u oplemenjivanju na sadržaj proteina. $G \times E$ interakcija za sadržaj proteina $u$ zrnu analizirana je pomoću linearno-bilinearnog AMMI-1 modela. Uticaj genotipa i sredine na ukupno variranje sadržaja proteina bio je približno jednak, dok se najmanja varijacija pripisuje interakciji $\mathrm{G} \times \mathrm{E}$. Veliki broj genotipova sa različitim sadržajem proteina (Korana, PI 180 507, Kabott, Krajina, Canatto) pokazao je mali doprinos interakciji u proučavanim sredinama. Među njima, najveći značaj imaju genotipovi sa natprosečnim sadržajem proteina, kao izvori za buduće programe oplemenjivanja.
\end{abstract}

Ključne reči: Glycine max, tehnološki kvalitet, AMMI-1 model

Primljen: 09.03.2020.

Prihvaćen: 28.05.2020. 